\title{
ISOLATION OF LEGIONELLA FROM COOLING TOWERS AND POTABLE WATER SYSTEMS IN HOSPITAL AND NON-MEDICAL BUILDINGS IN A UNIVERSITY CAMPUS
}

\author{
Chin $K S^{\prime}$, Rosli $A A^{\prime}$, Wee CSL $^{2}$ and Ngeow $\mathrm{YF}^{2}$ \\ 'MBBS Phase 2, Faculty of Medicine, University of Malaya, 50603 Kuala Lumpur \\ 2 Department of Medical Microbiology, Faculty of Medicine. University of Malaya, 50603 Kuala Lumpur
}

\begin{abstract}
Six cooling towers and eleven sources of potable water in a university campus in Kuala Lumpur were surveyed for the presence of legionellae. One nonmedical building cooling tower and three hot water systems from one ward of the hospital tested positive for Legionella, two of which contained Legionella pneumophila serogroup 1. The identification of Legionella was based on isolation, immunofluorescence and polymerase chain reaction (PCR). (JUMMEC 2003-2005; 8: 23-27)
\end{abstract}

KEYWORDS: Legionella isolation, hot water system, cooling towers

\section{Introduction}

Legionella spp. are Gram-negative bacteria that occur ubiquitously in soil and aquatic environments (I). The most well-known of these is Legionella pneumophila, which is the causative agent of Legionnaires' Disease, an atypical form of pneumonia characterized by a nonproductive cough coupled with pneumonia symptoms. Ever since its discovery in an air-conditioning system in 1976, this organism, along with other members of its genus, has been found with increasing frequency in both natural and man-made environments, especially in air-conditioning cooling towers and potable water systems (I-3). These organisms are dispersed in the form of aerosolized water droplets which, if inhaled by the susceptible, may be brought into the lungs where they cause disease.

Because of the Legionella organism's association with outbreaks of community and nosocomial pneumonia as well as a milder, self-limiting form of infection called Pontiac Fever, there has been an increasing need to monitor water systems for their presence, especially in hospital environments, where equipment relying on potable water sources, for example, humidifiers and nebulizers, which provide vehicles of transmission for these organisms, are used on a regular basis.

Until recently, there have been very few reports of Legionnaires' Disease in South-East Asia; however, several cases have been reported of late in Singapore (4) and China (5), in conjunction with the develop- ment of this region. In Malaysia, however, the last reported survey of the prevalence of Legionellae was carried out in 1990 (6). This paper describes a study carried out in 2002 as a follow-up of the study in a university campus in Kuala Lumpur.

\section{Methods}

\section{Media}

A commercial Buffered Charcoal Yeast Extract Agar with $\alpha$-ketoglutarate (Oxoid) supplemented with cysteine and ferric ions (Oxoid) and added with the selective agents glycine, vancomycin, polymyxin and cycloheximide (Oxoid) was used for the isolation of Legionella spp.

\section{Samples}

Water samples were collected from air-conditioning cooling towers and potable water systems from different sites in the university campus, including the university hospital according to the standard procedures of the American Public Health Association (APHA 1998). One litre of water was collected from

\section{Correspondence:}

CSL Wee

Department of Medical Microbiology

Faculty of Medicine

University of Malaya

50603 Kuala Lumpur

Tel: 603-7950 2205 
each cooling tower as well as hot water from taps and showers, using sterile bottles. These water samples were kept at $4^{\circ} \mathrm{C}$ and processed within 24 hours. Temperature and $\mathrm{pH}$ readings for the water samples were also determined by using a handheld temperature probe and $\mathrm{pH}$ indicator paper, respectively.

\section{Water processing}

The water samples were filtered by negative pressure through $47 \mathrm{~mm}$ polycarbonate membrane filters of $0.22 \mu \mathrm{m}$ pore size. The filter membranes were subsequently washed in $10 \mathrm{ml}$ sterile distilled water to dislodge any trapped organisms. The suspension was then centrifuged at $4,000 \mathrm{rpm}$ for 10 minutes. The supernatant was poured out, and the sediment was re-suspended in I $\mathrm{ml}$ of the original water sample.

\section{Acid buffer treatment}

The water samples were subjected to acid buffer treatment as described by Bopp et al (7). The $\mathrm{HCl}-\mathrm{KCl}$ buffer was prepared by mixing $3.9 \mathrm{ml}$ of $0.2 \mathrm{M} \mathrm{HCl}$ with $25 \mathrm{ml}$ of $0.2 \mathrm{M} \mathrm{KCl}$, producing a solution of approximately $\mathrm{pH}$ 2.2. The I ml suspensions were diluted I:I0 with the acid buffer and incubated at room temperature for 15 minutes. $0.1 \mathrm{ml}$ of each treated water sample was then removed from the acid suspension and inoculated onto BCYE- $\alpha$ agar by the spread plate method. The plates were incubated in a moist chamber at $37^{\circ} \mathrm{C}$ for up to 14 days.

\section{Screening suspect Legionella isolates}

Colonies which appeared after three to five days of incubation, and were greyish-white in colour with round edges and shiny appearance were presumed to be Legionella. These suspect isolates were plated onto Horse Blood Agar (HBA) as well as BCYE- $\alpha$ agar and incubated at $37^{\circ} \mathrm{C}$. Legionella-like organisms were identified by positive growth on BCYE- $\alpha$ agar but absence of growth on HBA. Verification of Legionella was carried out by a direct immunofluorescence assay (Legionella Direct Fluorescent Test System, Scimdex Corp., USA) and DNA amplification.

\section{DNA extraction and amplification}

A loopful of each suspected Legionella isolate was suspended in $200 \mu$ of TBE buffer $(5 \mathrm{mM}$ Tris, $5 \mathrm{mM}$ boric acid, 0.1 mM EDTA), $\mathrm{pH}$ 8.0. The suspensions were centrifuged at $10,000 \mathrm{~g}$ for 30 minutes to pellet the bacterial cells. The cells were then lysed with lysis buffer containing $0.5 \%(\mathrm{v} / \mathrm{v})$ Nonidet P-40, $0.5 \%$ Tween $20(\mathrm{v} / \mathrm{v})$ and $0.1 \mathrm{mg} / \mathrm{mL}$ Proteinase $\mathrm{K}$ at $60^{\circ} \mathrm{C}$ for one hour. The enzymes were subsequently deactivated by boiling the mixture at $100^{\circ} \mathrm{C}$ for 10 minutes. The extracts were then stored at $-20^{\circ} \mathrm{C}$ until use.
Amplification of the DNA was carried out using primers that amplified a 386-bp region of the Legionella I6S rRNA, as described by Jonas et al (8). The two 20-base oligonucleotides (5'-AGGGTTGATAGGTTAAGAGC-3' (JFP) and 5'-CCAACAGCTAGTTGACATCG-3' (JRP)) were complementary to positions 45 I to 470 , and 836 to 817 respectively.

Polymerase chain reaction (PCR) was performed in a $40 \mu$ reaction mixture containing IX PCR buffer (20 $\mathrm{mM}$ Tris- $\mathrm{HCl}$ (pH 8.4), $50 \mathrm{mM} \mathrm{KCl}$ ), $3.0 \mathrm{mM} \mathrm{MgCl}$, $200 \mu \mathrm{M}$ of dNTP (dATP, dCTP, dGTP, dTTP), I $\mu \mathrm{M}$ of each primer, $2 U$ of Platinum Taq DNA polymerase (Invitrogen, USA) and $4 \mu$ l of each extracted template DNA. Thermal cycling was performed on a PTC$100^{\mathrm{TM}}$ progammable thermal controller (MJ Research, Inc. USA). The cycling conditions began with a 5-minute hot start at $95^{\circ} \mathrm{C}$ to activate the DNA polymerase and was followed by 35 cycles consisting of $95^{\circ} \mathrm{C}$ for $45 \mathrm{~s}$, $57^{\circ} \mathrm{C}$ for $45 \mathrm{~s}$, and $72^{\circ} \mathrm{C}$ for $60 \mathrm{~s}$, ending with a final extension at $72^{\circ} \mathrm{C}$ for 10 minutes. The mixture was held at room temperature until analysis by gel electrophoresis.

Ten $\mu$ l of each amplified product was mixed with $5 \mu \mathrm{l}$ of loading buffer and electrophoresed on I.5\% agarose gel containing ethidium bromide, in TBE buffer at $90 \mathrm{~V}$ for 45 minutes. The gel was viewed on a UV transilluminator. The migration distance of the amplified fragment was compared to that of the Gene Ruler I00-bp marker to determine its approximate size.

\section{Results}

Out of the 17 water samples collected, four yielded Legionella-like organisms. All four isolates grew on BCYE- $\alpha$ after three to eight days of incubation, forming shiny grayish-white colonies with round edges. These were presumed to be Legionella by their inability to grow on HBA, which did not contain cysteine. DNA amplification yielded bands of 386-bp size (Figure I), confirming their identity as Legionella spp., and direct fluorescence assay using monoclonal antibodies determined that two of the four isolates were L. pneumophila serogroup I. The remaining two were non-reactive with the $L$. pneumophila serogroup I antiserum but were identified as Legionella by PCR.

Table I shows the breakdown of isolation based on sampling site. Out of a total of 17 sites around the university campus, six were from non-hospital groundbased cooling towers from various faculties that could be accessed without written permission. The remaining I I were from different sites in the university hospital where potable water was available, namely the taps and showers in ward bathrooms. One of the six 


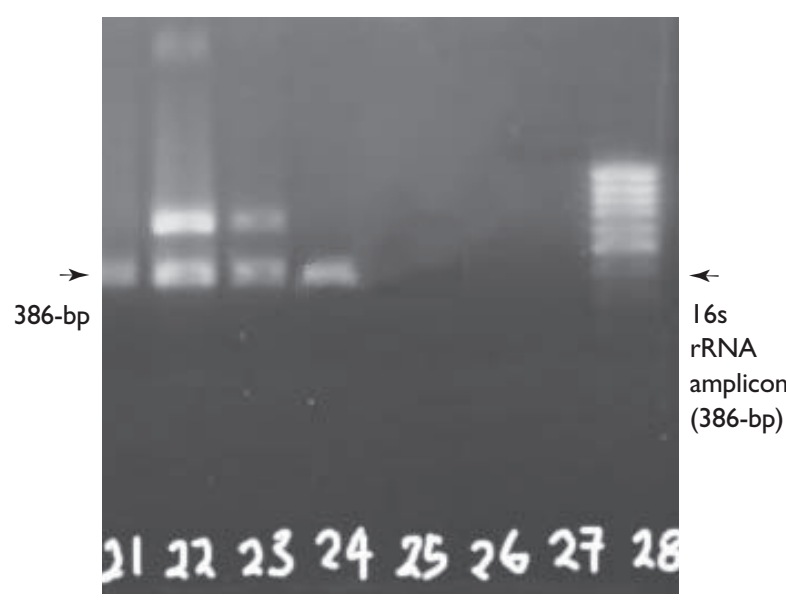

Figure I. Gel electrophoresis picture of 16s rRNA gene PCR for Legionella spp. Lanes 21-24: water samples positive for Legionellae; lanes 25-27: negative controls; lane 28: 100-bp marker.The specific I6s rRNA amplicon appears as a 386-bp band. The second (649-bp) band in lanes 22 and 23 is the product of amplification of a virulence gene in Legionella pneumophila (not described in this study). cooling towers tested positive for Legionella. The other three samples that yielded Legionellae were two hot water taps and a shower head from a paediatrics ward of the hospital. This gives an overall isolation rate of $23.5 \%$ ( $16.7 \%$ from the water cooling towers and $27.3 \%$ from hospital warm water supplies).

The mean $\mathrm{pH}$ and temperature of the water samples obtained from the cooling towers and wards are as shown in Table I. Hot water systems in the hospital were targeted for sampling because, as previously reported, (a) Legionellae can multiply in waters of temperatures that are not favourable to many other pathogens, and (b) these organisms are found more frequently and in larger numbers in hot water systems than cold water systems.

\section{Discussion}

The isolation of Legionella from natural waters without association with disease (3) was the first indication that this organism was not merely an accidental contaminant in the air-conditioning cooling tower involved

Table I. Breakdown of isolation based on sampling site

\begin{tabular}{|c|c|c|}
\hline Sample Type & Cooling Towers & Ward Hot Water Supply \\
\hline Sampling location & $\begin{array}{l}\text { - Pathology department } \\
\text { - Business faculty I } \\
\text { - Business faculty } 2 \\
\text { - Symphonic Band headquarters } \\
\text { - Hospital I } \\
\text { - Hospital } 2\end{array}$ & $\begin{array}{l}\text { Adult Oncology Unit } \\
\text { - Bone marrow transplant bathroom } \\
\text { shower head } \\
\text { - Water tap I } \\
\text { - Water tap } 2 \\
\text { Milk kitchen } \\
\text { - Preparation area tap } \\
\text { - Wash area I } \\
\text { - Wash area } 2 \\
\text { Paediatrics } 4 \text { ward } \\
\text { - Shower head } \\
\text { - Water tap (dirty utility room) } \\
\text { - Water tap (clean utility room) } \\
\text { Intensive Care Unit (ICU) } \\
\text { - Water tap I } \\
\text { - Water tap } 2\end{array}$ \\
\hline Total no. sampled & 6 & 11 \\
\hline No. positive for Legionella & 3 & 3 \\
\hline Mean $\mathrm{pH}$ of water & 4.7 & 4.6 \\
\hline Mean temperature $\left({ }^{\circ} \mathrm{C}\right)$ & 31.2 & 46.6 \\
\hline
\end{tabular}


in the 1976 Philadelphia outbreak, but actually dwelled in aquatic habitats. Since then, there have been reports of Legionella being found in potable water systems such as plumbing systems $(3,9)$, and luxury items such as fountains, spas (I0) and misting devices (II).

In our study, we have pinpointed certain areas in a university hospital as harbouring Legionella. Two of the four sites were found to be contaminated with L. pneumophila serogroup I, which is responsible for $50-70 \%$ of Legionnaires' Disease cases (8), and the two other sites by non-serogroup I Legionella. The detection rate of $23.5 \%$ is somewhat lower than the $40 \%$ previously reported from this country and its neighbour (6); however, the lower detection rate may be accounted for by the filtration isolation technique, which has a reported success rate of $53 \%$, and the acid buffer treatment which, while necessary to eliminate other microorganisms in the water, has been reported to reduce the recovery rate by $30 \%$ (I2). With the development of molecular biology, it may be more prudent to couple these tools with traditional culture methods to increase detection accuracy and sensitivity in future studies.

It has long since been established that Legionella infests waters as intracellular parasites of amoebae and protozoa. This carries serious implications since it has recently been shown that not only does this provide Legionella with sanctuary from harsh environmental conditions (13) - and thus increases its resistance against elimination by chemical methods - it also enhances its infectivity (14). In the hospital environment especially, its proliferation in plumbing systems is encouraged by the relatively high temperature of the water which, while hot enough to eliminate most other pathogens, is usually not high enough to kill Legionella spp. as they thrive in temperatures of about $32-42^{\circ} \mathrm{C}(1,3)$, although they cannot survive temperatures of over $60^{\circ} \mathrm{C}$. This study found that the Legionellae were able to survive in hospital hot water systems with an average water temperature of $46^{\circ} \mathrm{C}$.

Many previous studies have reported heavy contamination of Legionella in the plumbing systems of hospitals and other health care facilities $(3,15)$, and these organisms have been associated with nosocomial outbreaks $(5,7,12,14)$. The presence of Legionella in the hot water supply to the paediatrics ward poses a potential infection hazard as immunocompromised patients in the ward would be at risk for Legionnaires' Disease; furthermore, Legionella pneumophila has been associated with bacteremic coinfection (16).
Until recently there has been very little concern about this disease in this region, and there is no data regarding the extent of endemic Legionella infections in Malaysia (6); however, the case reports from Singapore (4) and China (5) serve as warning of the health issues Malaysia may face in the future, especially since there is a fast-growing trend towards the use of misting devices in both places of residence and public locations. If legionellosis is to be avoided, especially in health care establishments, then monitoring of water supplies and chemical disinfection with oxidizing agents or thermal disinfection (I7), coupled with regular scouring of the cooling towers to remove the slime and sediments that would harbour Legionellae should be carried out as a preventive measure, and not as corrective action after disease occurs.

\section{References}

I. Yee RY, Wadowsky RM. Multiplication of Legionella pneumophila in unsterilized tap water. Appl Environ Microbiol 1982; 43:1330-34.

2. Hsu SC, Martin R, Wentworth BB. Isolation of Legionella species from drinking water. Appl Environ Microbiol 1984; 48:830-32.

3. Wadowsky RM, Yee RB, Mezmar L, et al. Hot water systems as sources of Legionella pneumophila in hospital and non-hospital plumbing fixtures. Appl Environ Microbiol 1982; 43: I 104-II0.

4. Goh KT, Ed. Surveillance of Legionellosis and Legionella bacteria in Singapore, 1999. Epidemiol Bull 2000; 26:3944.

5. Chen YS, Lin WR, Liu YC, et al. Residential water supply as a likely cause of community-acquired Legionnaires' Disease in an immunocompromised host. Eur J Clin Microbiol Infect Dis 2002; 21:706-09.

6. Ngeow YF, Tan CH, Lim SY. Legionella species isolated from cooling towers in Kuala Lumpur. Med J Malaysia 1992; 47:15-19.

7. Bopp CA, Sumner JW, Morris GK, et al. Isolation of Legionella spp. from environmental water samples by low-pH treatment and use of a selective medium. J Clin Microbiol 1981; 13:714-19.

8. Jonas D, Rosenbaum A, Weyrich S, et al. Enzyme-linked immunoassay for detection of PCR-amplified DNA of Legionellae in bronchoalveolar fluid. J Clin Microbiol 1995; 33:1247-52.

9. Tobin JO'H, Beare J, Dunnill MS. Legionnaires' Disease in a transplant unit: isolation of the causative agent from shower baths. Lancet 1980; 2:1 I8-I2I. 
10. Hershey J, Burrus B, Marcussen V, et al. Legionnaires' Disease Associated with a Whirlpool Spa Display Virginia, September-October, 1996. MMWR 1997; 46: 83-6.

I I. LaMaire W, Jackson H, McFarland L. Epidemiologic Notes and Reports: Legionnaires' Disease OutbreakAssociated with a Grocery Store Mist Machine - Louisiana, 1989. MMWR 1990; 39:108-II0.

12. Boulanger CA, Edelstein PH. Precision and accuracy of recovery of Legionella pneumophila from seeded tap water by filtration and centrifugation. Appl Environ Microbiol 1995; 61:1805-09.

13. Gao LY, Harb OS, Kwaik YS. Utilization of similar mechanisms by Legionella pneumophila to parasitize two evolutionarily distant host cells, mammalian macrophages and protozoa. Infect Immun 1997; 65:4738-46.
14. Cirillo JD, Falkow S, Tompkins LS. Growth of Legionella pneumophila in Acanthamoeba castellanii enhances invasion. Infect Immun 1994; 62:3254-6I.

15. Sabria M,Yu VL. Hospital-acquired Legionellosis: solutions for a preventable infection. Lancet Infect Dis 2002; 2:368-73.

16. Tan MJ, Tan JS, File TM Jr. Legionnaires' Disease with bacteremic coinfection. Clin Infect Dis 2002; 35:533-9.

17. Kim BR,Anderson JE, Mueller SA, et al. Literature review - efficacy of various disinfectants against Legionella in water systems. Water Res 2002; 36:4433-44. 